\title{
Imatinib ile indüklenen eritrodermi olgusu
}

\section{A case of imatinib-induced erythrodermia}

\section{Ișıl Bulur, Zeynep Nurhan Saraçoğlu, Emine Böyük, Funda Canaz* \\ Eskișehir Osmangazi Üniversitesi Tıp Fakültesi, Deri ve Zührevi Hastalıkları, * Patoloji Anabilim Dalı Eskișehir, Türkiye}

\section{Özet}

İmatinib kronik myeloid lösemi (KML) tedavisinde kullanılan ilk moleküler hedeflenmiş ilaçtır. İmatinibin indüklediği advers kutanöz reaksiyonlar sıktır ve genellikle orta şiddetlidir. Diğer taraftan imatinib ile indüklenen eritrodermi nadir olarak gözlenir ve literatürde sadece birkaç olgu yer almaktadır. Bu yayında KML hastasında imatinibin indüklediği eritrodermi olgusu sunulmaktadır. (Türkderm 2014; 48: 54-6)

Anahtar Kelimeler: Imatinib, eritrodermi, deri reaksiyonları

\section{Summary}

Imatinib is the first molecularly targeted drug developed for the treatment of chronic myeloid leukemia (CML). Adverse cutaneous reactions induced by imatinib are frequent and generally moderate. On the other hand, imatinib-induced erythroderma is an uncommon reaction, and only a few cases have been reported in the literature. In this paper, we report a case of erythrodermia induced by imatinib in a patient with CML. (Turkderm 2014; 48: 54-6)

Key Words: Imatinib, erythrodermia, cutaneous reactions

\section{Giriş}

İmatinib mesylate kanser tedavisinde ilk olarak kullanılan tirozin kinaz inhibitörlerindendir. Imatinib ve imatinibin rezistans olduğu olgularda kullanılan ikinci jenerasyon ürünler olan dasatinip ile nilotinipin etkisi sadece tümör hücrelerine karşı olmayıp dermatoloji kliniklerinde de ilaç gruplarının kutanöz yan etkileri ile sıkça karşılaşılmaktadır ${ }^{1}$. Kutanöz reaksiyonların sıklıkla doz bağımlı olarak geliştiği kabul edilse de nadir olarak düşük dozlarda doz bağımsız olarak gelişen ciddi reaksiyonlar da literatürde yer almaktadır². Bu yayında düşük doz imatinibe bağlı gözlenen eritrodermi olgusu sunulmaktadır.

\section{Olgu}

Yetmiş iki yaşında erkek hasta kliniğimize yüzde şişlik ve vücutta yaygın kızarıklık nedeniyle başvurdu. Hastanın öyküsünden şikayetlerinin ilk kez iki hafta önce yüzde özellikle göz kapakları çevresinde şişlik ile başladığı, birkaç gün sonra da tüm vücutta yaygın kızarıklık geliştiği öğrenildi. Hasta diyabetes mellitus, koroner arter hastalığı nedeni ile uzun süredir repaglinid, metformin, quinapril, asitsalisilik asit aldığını ve son altı haftadır da KML tanısı ile 400 mg/gün imatinib kullandığını belirtti. Hastanın dermatolojik muayenesinde tüm vücutta şiddetli kaşıntının eşlik ettiği yüzde ödem, yaygın eritem, deskuamasyon, bilateral el palmar bölgede ve ayak plantar

Yazışma Adresi/Address for Correspondence: Dr. Işıl Bulur, Eskişehir Osmangazi Üniversitesi Tıp Fakültesi, Deri ve Zührevi Hastalıkları Anabilim Dall, Eskişehir, Türkiye GSM: +90 5326477504 E-posta: isilbulur@yahoo.com Geliş Tarihi/Received: 18.11.2013 Kabul Tarihi/Accepted: 26.12.2013

Türkderm-Deri Hastalıkları ve Frengi Arșivi Dergisi, Galenos Yayınevi tarafından basılmıștır. Turkderm-Archives of the Turkish Dermatology and Venerology, published by Galenos Publishing. 
bölgede hiperkeratoz gözlendi (Resim 1). Fizik muayenesinde lenfadenopati ve hepatosplenomegali tespit edilmedi, mukozalarda lezyon gözlenmedi. Tam kan sayımında $\mathrm{Hb} 11,7 \mathrm{~g} / \mathrm{dl}$, beyaz küre $7700 /$ ul, platelet 280,000/ul, eozinofil 4100/ul, eozinofil yüzdesi \%47,2'ydi. Karaciğer fonksiyon testleri ve böbrek fonksiyon testleri normal sınırlardaydı. Hastadan ilaç erüpsiyonu tanısı ile deri biyopsisi alındı. Histopatolojik incelemede epidermiste parakeratoz, granüler tabaka kaybı, spongiozis, hidropik dejenerasyon, lenfosit ekzositozu, diskeratozis, yüzeyel dermiste perivasküler ve interstisyel lenfohistiyositler, eozinofilik polimorf nüveli lökositler görüldü (Resim 2a, b). Hastada klinik ve histopatolojik bulgular eşliğinde imatinib tedavisine bağlı gelişsen eritrodermi düşünüldü. Hematoloji bölümü tarafından imatinib tedavisi kesildi. Hastaya $1 \mathrm{mg} / \mathrm{kg}$ dozundan oral prednizolon tedavisi başlandı. Tedavi ile şikayetleri gerileyen hastaya hematoloji bölümü tarafından 100 mg/gün imatinib tedavisi başlandı. Hastanın yüzde ödem ve deride kızarıklık şikayeti imatinib tedavisinin tekrar başlanmasından iki gün sonra tekrarladı. Hastanın imatinib tedavisi ile şikayetlerinin tekrarlaması ve istenilen etkin dozun verilememesi nedeniyle hematoloji bölümü tarafından KML'ye yönelik tedavisi dasatinip tedavisi ile değiştirildi. Lezyonlarına topikal kortikosteroid önerildi.

\section{Tartışma}

İmatinib bcr-abl tirozin kinazın selektif inhibitörüdür, başlıca kronik myeloid lösemi, akut lenfoblastik lösemi, metastatik veya rezekte edilmeyen gastrointestinal stromal tümörlerde kullanılır ${ }^{3,4}$. Inhibitör aktivitesi bcr-abl, stem cell factor receptor (c-KIT) ve platelet derived growth factor receptor (PDGFR)'ne karşıdır ${ }^{4}$. PDGFR ve C-KIT'in epidermal homeostazis üzerinde etkisi olduğu ve epidermal inflamasyonu başlattıkları yakın zamanda yapılan çalışmalarda gösterilmiştir ${ }^{5}$.

Imatinibe bağlı gözlenen kutanöz yan etkiler imatinibin nonhematolojik yan etkileri arasında en sık görüleni olup \%17-38 oranında gözlenir ${ }^{6}$. Kutanöz yan etkiler sıklıkla doz bağımlı olup doz azaltılması ile kontrol altına alınabilir². Düşük dozlarda (200-600 mg/

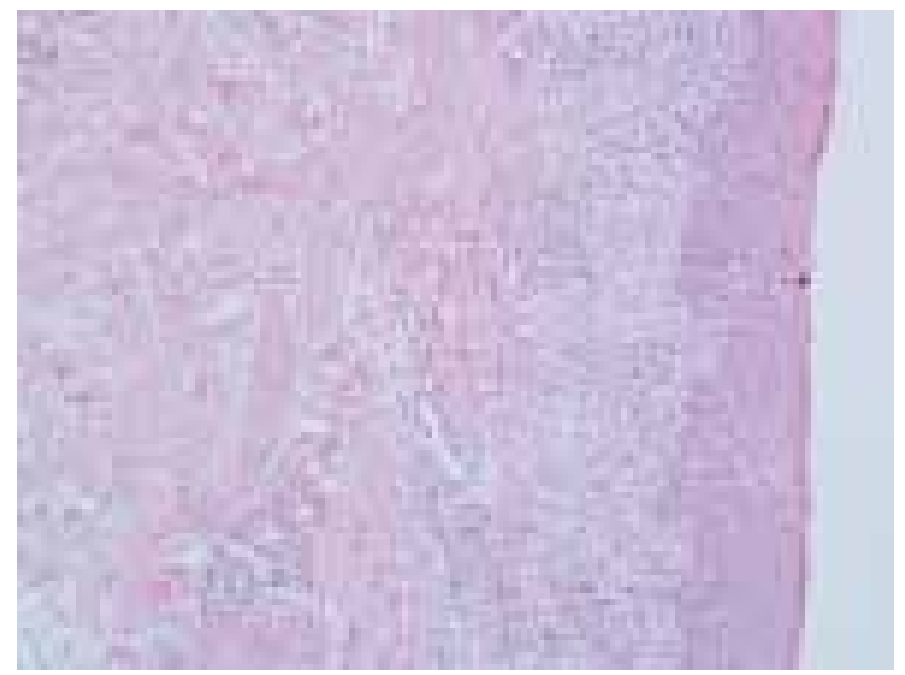

Resim 2a. Epidermiste spongiozis, diskeratotik hücreler, lenfosit ekzositozu ve granüler takaba kaybı, yüzeyel dermiste perivasküler ve interstisyel lenfohistiyositik inflamatuar infiltrasyonu (x100, H\&E)

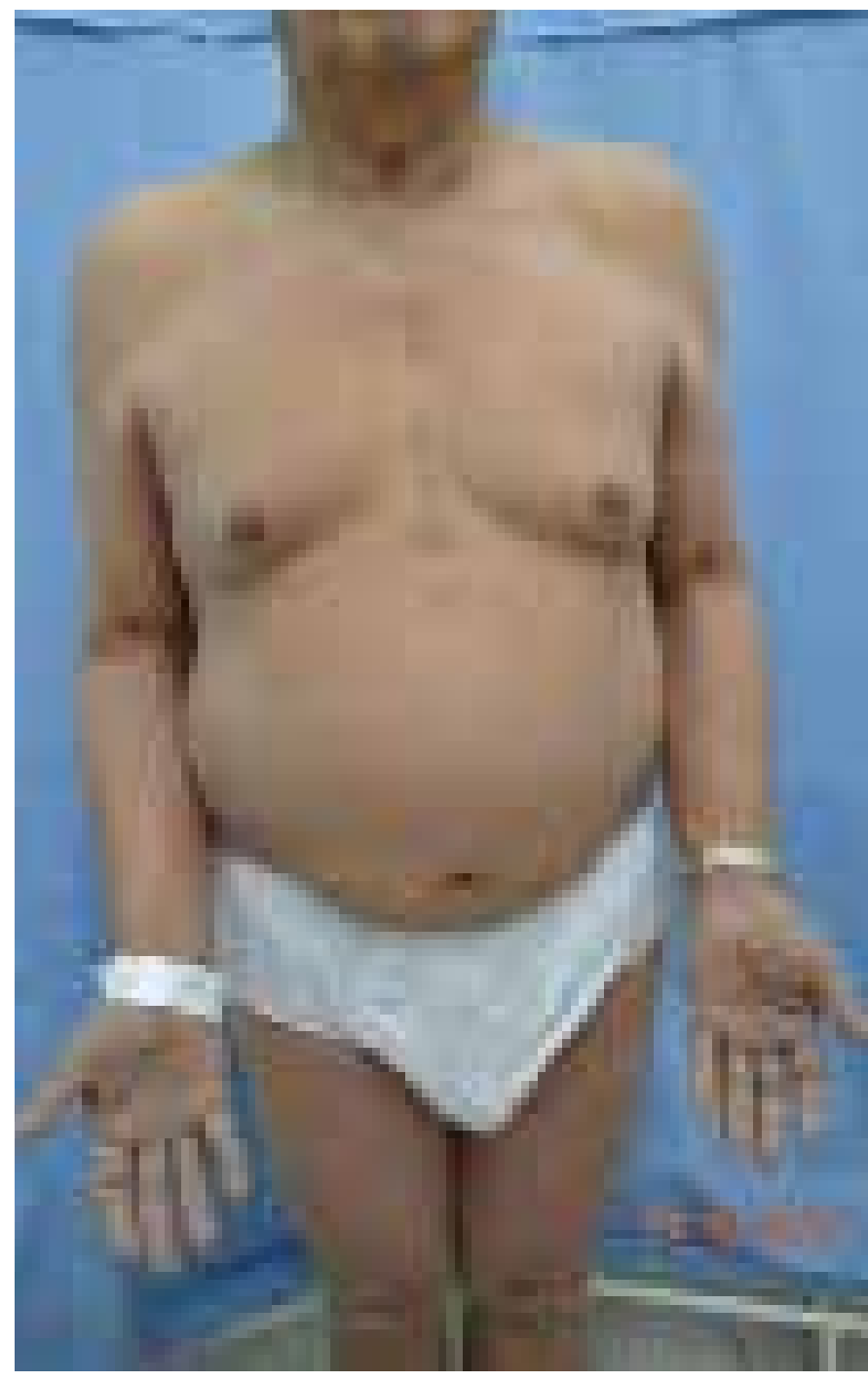

Resim 1. Gövde ön yüzde, her iki alt ve üst ekstremitede yaygın eritem, deskuamasyon ile bilateral palmar hiperkeratoz

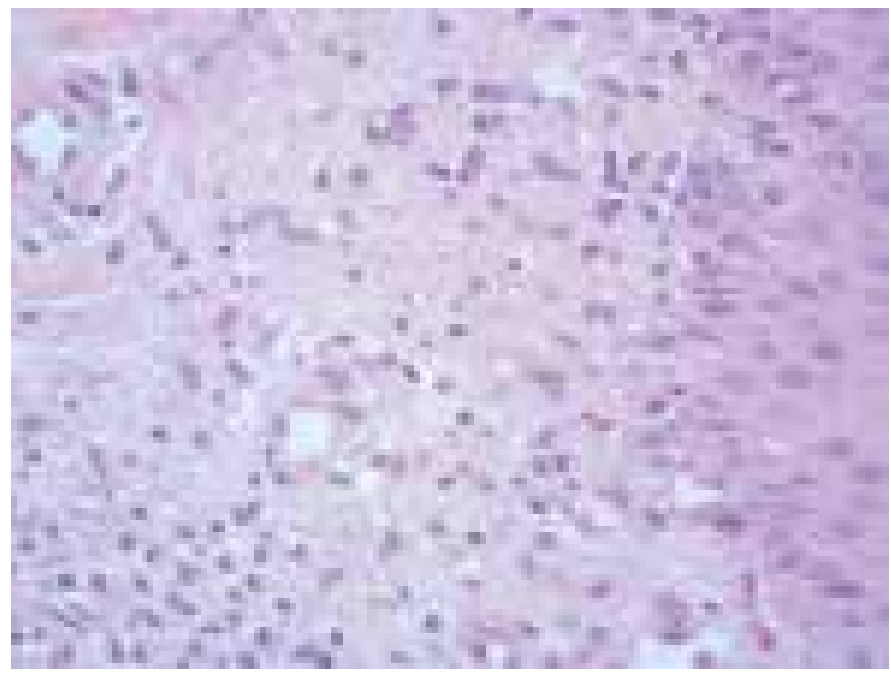

Resim 2b. Yüzeyel dermiste eozinofilik polimorf nüveli lökosit infiltrasyonu $(x 400, H \& E)$ 
gün) hafif reaksiyonlar gözlenirken yüksek dozlarda (600-1000 mg/ gün) ciddi erüpsiyonlar gözlenmektedir ${ }^{2,6,7}$. En sık görülen reaksiyonlar kaşıntı, yüzde ödem, hipo-hiperpigmentasyondur. Alopesi, likenoid reaksiyon, pitriyaziform erüpsiyon, mikozis fungoides benzeri reaksiyon, küçük damar vasküliti, psoriasis nadir görülen kutanöz yan etkilerdendir ${ }^{1,4}$. Steven-Johnson Sendromu, toksik epidermal nekroliz, akut jeneralize ekzantematöz reaksiyon, eritrodermi gibi ciddi kutanöz yan etkiler imatinib kullanan hastaların \%1'inden azında görülmektedir ${ }^{4}$. Literatürde imatinibe bağlı eritrodermi ise az sayıda olguda raporlanmıştır ${ }^{2,3,6-8}$.

Imatinibin kutanöz reaksiyon oluşturma mekanizması netlik kazanmamıştır ${ }^{1}$. Literatürdeki vakalar değerlendirildiğinde kutanöz yan etkilerin doz bağımlı olduğu ve yan etkilerin ilacın farmakolojik etkilerinden kaynaklandığını şeklindedir². Ancak özellikle eritrodermi gibi ciddi reaksiyonlarda, düşük doza rağmen ilaç değişimini gerektirecek yan etkilerin devam etmesi kutanöz yan etkilerin hipersensitivite reaksiyonu olabileceğini de düşündürmektedir². Ciddi kutanöz yan etkilerin tedavisinde topikal steroid ve antihistaminik tedavisine ek olarak sistemik steroid kullanımı ve ilaca ara verilmesi gerekebilmektedir. Tekrarlayan kutanöz yan etkilerde reaksiyonların önlenmesi için desensitizasyon protokolü öneren yayınlar da bulunmaktadır1,2. Olguların çoğunda ise imatinibe yeniden başlandığında daha kısa sürede reaksiyonun tekrarlamasından dolayı başka bir tedavi ajanına geçilmesi gündeme gelmektedir ${ }^{4,8}$. Bizim olgumuzda ise hematoloji bölümü tarafından tekrarlanan düşük doza karşı da reaksiyon gelişmesi nedeniyle ilaç değişimi düşünülerek dasatinip tedavisine geçilmiştir.

Olgumuzda düşük doz imatinib tedavisi ile eritrodermi görülmesi ve ilacın tekrar alınması ile şikayetlerinin tekrarlaması literatürde az sayıda olguda tanımlanan kutanöz yan etkilerin hipersensitivite reaksiyonu olabileceği hipotezini kuvvetlendirmektedir.

\section{Kaynaklar}

1. Brazzelli V, Grasso V, Borroni G: Imatinib, dasatinib and nilotinib: a review of adverse cutaneous reactions with emphasis on our clinical experience. J Eur Acad Dermatol Venereol 2013;27:1471-80.

2. Vano-Galvan S, Fernandez-Guarino M, Henriquez-Santana A, et al: Imatinibinduced erythroderma mediated by an unusual non-dose-dependent mechanism. Eur J Dermatol 2007;17:538-9.

3. Banka N, Aljurf M, Hamadah I: Imatinib (STI-571)-induced exfoliative dermatitis in a Saudi patient with deck chair sign. Dermatology 2003;207:329-30

4. Hwang JE, Yoon JY, Bae WK, et al: Imatinib induced severe skin reactions and neutropenia in a patient with gastrointestinal stromal tumor. BMC Cancer 2010;10:438.

5. Kuraishi N, Nagai $Y$, Hasegawa M, et al: Lichenoid drug eruption with palmoplantar hyperkeratosis due to imatinib mesylate: a case report and a review of the literature. Acta Derm Venerol 2010;90:73-6.

6. Mathew T, Chandrashekar L, Pulimood S, et al: Imatinib-induced erythroderma. Australas J Dermatol 2007;48:193-4.

7. Oztas P, Erbasi S, Lenk $\mathrm{N}$,et al. Imatinib-induced erythrodermia in a patient with chronic myeloid leukemia. Acta Derm Venereol 2006;86:174-5.

8. Sanghavi SA, Dongre AM, Khopkar US: Imatinib mesylate induced erythroderma. Indian J Dermatol Venereol Leprol 2012; 78: 408. 